\title{
Penerapan Model Discovery Learning Dalam Upaya Meningkatkan Kemampuan Pemahaman Matematis Dan Pemecahan Masalah Matematis
}

\author{
Abdul Mugni ${ }^{1 *}$, Didi Turmudzi ${ }^{2}$, Bana G. Kartasasmita ${ }^{3}$ \\ ${ }^{1}$ Program Studi Pendidikan Guru Madrasah Ibtidaiyyah, STAI Persis Garut \\ 2,3Program Studi Magister Pendidikan Matematika, Universitas Pasundan \\ *abdulmugni@staipersisgarut.ac.id
}

\begin{abstract}
Abstrak
Abstrak : Penelitian mix method dengan tipe embedded design ini bertujuan untuk mengetahui peningkatan dan perbedaan peningkatan kemampuan pemahaman matematis dan kemampuan pemecahan masalah matematis antara siswa yang mendapatkan model discovery learning dengan siswa yang mendapatkan pembelajaran konvensional. Populasi pada penelitian ini adalah seluruh siswa kelas VII MTs Persis Pasirwangi dengan sampel sebanyak dua kelas, yaitu: kelas VII-C yang menggunakan model discovery learning dan kelas VII-D yang menggunakan pembelajaran Konvensional. Instrumen pengumpulan data dalam penelitian: tes kemampuan pemahaman matematis dan kemampuan pemecahan masalah matematis. Dari hasil analisis penelitian diperoleh : 1) Tidak adanya perbedaan peningkatan kemampuan pemahaman matematis siswa antara siswa yang mendapatkan model discovery learning dengan siswa yang mendapatkan pembelajaran konvensional, 2) Terdapat perbedaan peningkatan kemampuan pemecahan masalah matematis siswa antara siswa yang mendapatkan model discovery learning dengan siswa yang mendapatkan pembelajaran konvensional ditinjau dari KAM ( Tinggi, Sedang, dan Rendah), 3) Effect size dari pembelajaran discovery learning terhadap peningkatan kemampuan pemahaman dan kemampuan pemecahan masalah matematis tergolong kedalam kategori sedang.
\end{abstract}

Kata Kunci: Discovery Learning, Effect Size, Kemampuan Pemahaman Matematis, Kemampuan Pemecahan Masalah Matematis,.

\begin{abstract}
The research of mix method with the type of embedded design is aimed to know the improvement and the difference of the improvement of mathematical understanding ability and mathematical problem solving ability among the students who get the discovery learning model with the students who get the conventional learning. The population in this study is all students of class VII MTs Persis Pasirwangi with two classes of samples, namely: class VII-C using discovery learning model and class
\end{abstract}


VII-D using conventional learning. Instruments used in research: mathematical comprehension ability test and mathematical problem solving ability. From result of research analysis obtained: 1). There is no difference in the improvement of students' mathematical understanding among students who get discovery learning model with students who get conventional learning, 2). There is a difference in the ability of students to solve mathematical problems between students who get discovery learning model with students who get conventional learning in terms of KAM (High, Medium, and Low), 3) .Effect size of learning discovery learning to improve understanding ability and problem solving ability mathematically fall into the category of being.

Keywords : Ability, Discovery Learning, Effect Size, Ability of Mathematical Understanding, Mathematical Problem Solving.

\section{Pendahuluan}

Matematika merupakan mata pelajaran yang menduduki peranan penting dalam kehidupan sehari-hari dan dalam pendidikan, hal ini dapat dilihat dari waktu jam pelajaran yang lebih banyak dibandingkan pelajaran lain serta salah satu mata pelajaran yang diujikan sesuai dengan standar nasional. Menyadari pentingnya pembelajaran matematika di Sekolah, Pemerintah sebagai pelaku kebijakan terhadap pendidikan formal melalui Undangundang RI No. 20 Tahun 2003 tentang Sikdiknas (Sistem Pendidikan Nasional) pasal 37 menegaskan bahwa mata pelajaran matematika merupakan salah satu mata pelajaran wajib bagi siswa pada jenjang pendidikan dasar dan menengah. Marpaung (2004) "Kualitas pendidikan matematika Indonesia dalam skala nasional masih rendah".

Kemampuan pemecahan masalah ini erat kaitannya dengan komponen pemahaman siswa dalam bermatematika. Polya (dalam Ramadhani, 2017) menyatakan bahwa tahapan pertama dalam memecahkan masalah matematika adalah memahami masalah matematika itu sendiri. Dengan demikian, kemampuan pemahaman matematis merupakan langkah dasar untuk memecahkan suatu masalah, dan diharapakan jika kemampuan pemahaman matematis siswa meningkat bisa mempengaruhi peningkatan kemampuan pemecahan masalah matematik.

Berdasarkan uraian di atas, kaitan antara kemampuan pemahaman dengan pemecahan masalah dapat dipertegas bahwa, jika seseorang telah memiliki kemampuan pemahaman 
terhadap konsep-konsep matematika, maka ia mampu menggunakannya untuk memecahkan masalah. Sebaliknya, jika seseorang dapat memecahkan suatu masalah, maka orang tersebut harus memiliki kemampuan pemahaman terhadap konsep-konsep matematika yang telah dipelajari sebelumnya. Hal ini diperkuat dengan hasil penelitian Nurliani (2014) yang menyatakan bahwa terdapat korelasi antara kemampuan pemecahan masalah dengan pemahaman matemtis siswa yang menggunakan model pembelajaran berbasis masalah.

Kemampuan pemahaman dan kemampuan pemecahan masalah matematis merupakan hal yang sangat penting, karena selain para siswa mencoba menjawab pertanyaan atau memecahkan masalah-masalah mereka, mereka juga termotivasi untuk berkerja keras dalam memahami konsep matematika yang terdapat pada masalah tersebut. Sehingga apabila siswa telah menguasai kemampuan pemahaman dapat mempermudah dalam memecahkan suatu masalah matematis sehingga dimungkinkan mereka dapat mampu lebih analitis dan mengaplikasikan kemampuan tersebut dalam kehidupan seharihari.

Meningat akan peranan penting matematika baik dalam kehidupan sehari-hari terlebih dalam dunia pendidikan, fenomena yang terlihat menunjukan bahwa hasil penelitian dari Programme for International Student Assessment (PISA) tahun 2012 yang mengukur kemampuan bidang membaca, matematik dan sains Indonesia berada diurutan 64 dari 65 negara. Selain itu, hasil PISA tahun 2015 Indonesia berada pada urutan 69 dari 76 negara. Survei tersebut menilai kemampuan siswa dalam memecahkan masalah, memformulasikan alasan dan mengkomunikasikan gagasan yang dimilikinya kepada orang lain. Bila dilihat fenomena tersebut hal yang wajar dengan ketuntuasan belajar siswa secara individual pada mata pelajaran matematika di Madrasah Tsanawiyah Persis Pasirwangi tergolong dalam katagori rendah pada mata pelajaran matematika.

Berikut penulis sajikan ketuntusan belajar siswa kelas VII MTs Persis Pasirwangi tahun 2016/2017 pada materi himpunan: 
Tabel 1 Rekapitulasi Ketuntasan Belajar Siswa kelas VII MTs Persis Pasirwangi Tahun 2016/2017

\begin{tabular}{cccc}
\hline Kelas & Ketuntasan & Ketidaktuntasan & KKM \\
\hline VII A & 16 Orang & 18 Orang & 65 \\
\hline VII B & 13 Orang & 21 Orang & 65 \\
\hline VII C & 16 Orang & 12 Orang & 65 \\
\hline VII D & 13 Orang & 15 Orang & 65 \\
\hline
\end{tabular}

Sumber : MTs Persis Pasirwangi Garut TA 2016-2017.

Berdasarkan hasil survei/obrolan bersama para guru yang dilakakukan penulis di MTs Persis Pasirwangi pada bulan September menyimpulkan bahwa rendahnya hasil belajar diatas adalah suatu hal yang wajar jika dilihat dari aktivitas pembelajaran dikelas yang tidak lain dalam penyampaian informasi lebih mengaktifkan guru, sementara siswa pasif mendengarkan. Diperkuat oleh pendapat Wahyudin (Komala, 2012:3) yang menemukan bahwa guru matematika pada umumnya mengajar dengan metode ceramah. Pada kondisi seperti itu, kesempatan siswa untuk menemukan dan membangun pengetahuan sendiri tidak ada. Mengembangkan motode pembelajaran merupakan salah satu cara membantu peserta didik memahami dan memecahkan permasalahan matematis. Motede pembelajaran yang diperkirakan mampu meningkatkan kemampuan pemahaman dan kemampuan pemecahan masalah yaitu metode Discovery Learning, metode tersebut menurut penulis mampu membantu peserta didik memperoleh pemecahan masalah yang baik. Discovery Learning (metode penemuan). Menurut Suryosubroto (dalam Heriawan, 2002:192) Discovery Learning adalah suatu prosedur mengajar yang mementingkan pengajaran perseorangan, manipulasi objek dan lain-lain, sebelum sampai kepada generalisasi. Discovery Learning merupakan komponen praktik pendidikan yang meliputi metode mengajar yang memajukan cara belajar aktif, berorientasi pada proses, mengarahkan sendiri, mencari sendiri, dan reflektif. Hamalik (dalam Widura, 2015) menyatakan bahwa discovery learning merupakan sistem dua arah dimana proses pembelajarannya melibatkan siswa dan guru. Dalam pembelajaran ini, guru bertindak sebagai pembimbing dan fasilitator yang mengarahkan peserta didik untuk menemukan konsep dalil, prosedur, algoritma, dan semacamnya. Metode ini menekankan guru untuk memberikan masalah kepada peserta didik kemudian peserta didik diarahkan untuk memahami masalah, memecahkan masalah 
tersebut melalui percobaan, mengumpulkan dan menganalisis data, dan mengambil kesimpulan.

Kelebihan dalam pembelajaran discovery menurut Bruner (dalam Hartono, 2016) yaitu motivasi yang meliputi motivasi instrinsik dan motivasi ekstrinsik. Discovery Learning diharapkan dapat meningkatkan peran aktif peserta didik dalam pembelajaran sehingga dapat meningkatkan kemampuan pemahaman matematis serta kemampuan pemecahan masalah matematis yang dapat dilihat dari hasil belajar peserta didik serta motivasi belajar peserta didik. Oleh sebab itu, maka akan dihitung pula tingkat keefektifan pembelajaran discovery learning terhadap peningkatan kemampuan pemahaman matematis dan kemampuan pemecahan masalah matematis, maka besarnya keefekktifan akan dihitung menggunakan rumus effect size yang dikemukakan oleh Cohen $-\mathrm{d}$.

Effect Size merupakan metode meta analisis Coe, (dalam Wati dan Fatimah, 2016) yang digunakan untuk menentukan efektifitas dari sebuah penelitian baik praktik atau teori, kontribusi relatif dari faktor yang berbeda atau faktor yang sama pada persoalan yang berbeda dan menunjukkan kekuatan sebuah analisis pada penelitian.

Tujuan dari penelitian yang ingin dicapai adalah : 1) untuk mengetahui perbedaan peningkatan kemampuan pemahaman matematis siswa antara yang mendapatkan discovery learning dengan yang mendapatkan konvensioanal, 2) untuk mengetahui perbedaan peningkatan kemampuan pemecahan masalah matematis siswa antara yang mendapatkan discovery learning dengan yang mendapatkan konvensioanal, 3) untuk mengetahui keefektifan model discovery learning terhadap kemampuan pemahaman dan kemampuan pemecahan masalah matematis.

\section{Metode Penelitian}

Jenis penelitian yang digunakan adalah eksperimen mix method denga tipe embedded deisgn ( Indrawan dan Yaniawati, 2014). Peneliti menggunakan desain ini dengan harapan temuan-temuan kualitatif membantu interpretasi hasil-hasil penelitian kuantitatif.

Subjek populasi pada penelitian ini adalah seluruh siswa kelas VII MTs Persis Pasirwangi dengan sampel sebanyak dua kelas, yaitu: kelas VII-C yang menggunakan model discovery learning dan kelas VII-D yang menggunakan pembelajaran Konvensional. 
Instrumen yang digunakan dalam pengumpulan data berbentuk tes uraian untuk mengukur kemampuan pemahaman matematis dan kemampuan pemecahan masalah matematis siswa, dimana instrument yang digunakan dikembangkan sesuai dengan indicator kemampuan pemahaman matematis dari Kilpatrick dan Findell (2001) dan indicator kemampuan pemecahan masalah matematis dari Sumarmo (2013). Teknik analisis data dalam penelitian ini menggunakan uji $\mathrm{t}$ untuk dua sampel saling bebas dan uji cohen-d untuk mengukur keefektifan model pembelajaran.

\section{Hasil Penelitian dan Pembahasan}

\section{Kemampuan Pemahaman Matematis}

Dari hasil perhitungan diperoleh nilai rata-rata kemampuan awal pemahaman matematis kelas eksperimen dan kelas kontrol adalah 42,77 dan 42,24 . Untuk rata-rata kemampuan akhir kemampuan pemahaman matematis kelas eksperimen dam kelas kontrol adalah 69,68 dan 62,53 . Sedangkan rata-rata indeks mutu peningkatan kemampuan pemahaman matematis kelas eksperimen dan kelas kontrol berturut-turut adalah 0,456 dan 0,358 .

Berdasarkan perhitungan hasil analisis indeks mutu peningkatan kemampuan pemahaman matematis diperoleh nilai Sig. berturut-turut untuk data kelas eksperimen dan kelas kontrol adalah 0,200 dan 0,200. Dengan kriteria suatu data berdistribusi normal adalah jika Sig. $>\alpha=0,05$. Maka dapat disimpulkan bahwa untuk data kelas eksperimen dan data kelas kontrol berdistribusi normal. Sedangkan uji homogentitas diperoleh perhitungan nilai Sig. 0,148 Dengan kriteria dua data dikatakan memilikia varians homogen adalah jika Sig. > $\alpha=0,05$. Karena nilai Sig. $>\alpha=0,05$, Maka dapat disimpulkan bahwa kedua data tersebut memiliki varians yang homogen.

Dengan bantuan IBM SPSS for Windows untuk pengujian hipotesis pertama menggunakan uji annova diperoleh nilai sig 0,805 , hal ini menjukan pada kriteria penerimaan Ho. Dengan demikian untuk hipotesis pertama dapat disimpulkan bahwa tidak terdapat perbedaan peningkatan kemampuan pemahaman matematis siswa antara siswa yang mendapatkan model pembelajaran discovery learning dengan siswa yang mendapatkan pembelajaran konvensional. 


\section{Kemampuan Pemecahan masalah matematis}

Dari hasil perhitungan diperoleh nilai rata-rata kemampuan awal pemahaman matematis kelas eksperimen dan kelas kontrol adalah 21,82 dan 23,03. Untuk rata-rata kemampuan akhir kemampuan pemahaman matematis kelas eksperimen dam kelas kontrol adalah 67,82 dan 55,74. Sedangkan rata-rata indeks mutu peningkatan kemampuan pemahaman matematis kelas eksperimen dan kelas kontrol berturut-turut adalah 0,579 dan 0,413.

Berdasarkan perhitungan hasil analisis indeks mutu peningkatan kemampuan pemahaman matematis diperoleh nilai Sig. berturut-turut untuk data kelas eksperimen dan kelas kontrol adalah 0,059 dan 0,200. Dengan kriteria suatu data berdistribusi normal adalah jika Sig. $>\alpha=0,05$. Maka dapat disimpulkan bahwa untuk data kelas eksperimen dan data kelas kontrol berdistribusi normal. Sedangkan uji homogentitas diperoleh perhitungan nilai Sig. 0,151 Dengan kriteria dua data dikatakan memilikia varians homogen adalah jika Sig. > $\alpha=0,05$. Karena nilai Sig. $>\alpha=0,05$, Maka dapat disimpulkan bahwa kedua data tersebut memiliki varians yang homogen.

Dengan bantuan IBM SPSS for Windows untuk pengujian hipotesis pertama menggunakan uji annova diperoleh nilai sig 0,017, hal ini menjukan berada pada kriteria penolakan Ho. Dengan demikian untuk hipotesis pertama dapat disimpulkan bahwa terdapat perbedaan peningkatan kemampuan pemecahan masalah matematis siswa antara siswa yang mendapatkan model pembelajaran discovery learning dengan siswa yang mendapatkan pembelajaran konvensional.

\section{Keefektifan Discovery Learning}

Besar pengaruh model pembelajaran discovery learning terhadap peningkatan kemampuan pemahaman matematis dan kemampuan pemecahan masalah matematis siswa dilakukan dengan dengan meghitung nilai Cohen $-d$ menggunakan rumus Effect size dari Cohen (dalam Hake, R.R, 2002) sebagai berikut :

$$
d=\frac{\overline{m_{t}}-\overline{m_{c}}}{\sqrt{\frac{S_{t}^{2}+S_{c}^{2}}{2}}}
$$

\section{Dimana :}

$d$ : Nilai Effect Size

$\overline{m_{t}}:$ Nilai rata-rata kelas eksperimen 
$\overline{m_{c}}:$ Nilai rata-rata kelas kontrol

$S_{t}:$ Standar deviasi kelaseksperimen

$S_{c}:$ Standar deviasi kelas kontrol

Dari hasil perhitungan Cohen $-d$ diperoleh nilai effect size pembelajaran discovery learning terhadap peningkatan kemampuan pemahaman matematis dan kemampuan pemecahan masalah matemtis adalah 0,40 dan 0,66. Dari hasil perthitungan effect size tersebut diklasifikasikan kedalam interpretasi Cohen ( dalam dalam Kotrlik, J W., 2011) pada Tabel 2 berikut :

Tabel 2

Interpretasi Nilai Effect Size

\begin{tabular}{cc}
\hline Interpretasi Effect Size & Keterangan \\
\hline$d \leq 0,2$ & Rendah \\
\hline $0,2<d \leq 0,8$ & Sedang \\
\hline$d>0,8$ & Tinggi \\
\hline
\end{tabular}

Dengan demikian dapat diakatakan bahwa pembelajaran discovery learning efektif dalam meningkatkan kemampuan pemahaman matematis dengan kategori keefektifan sedang dan kemampuan pemecahan masalah matematis dengan tingkat efektifan termasuk dalam kategori sedang juga.

\section{Pembahasan}

Pembahasan dan temuan hasil penelitian ini didasarkan pada aspek/indikator yang ditelaah dalam penelitian ini, meliputi pelaksanaan proses pembelajaran discovery learning, kemampuan pemahaman matematis, kemampuan pemecahan masalah matematis, ativitas siswa, dan motivasi siswa.

\section{Pembelajaran Discovery Learning}

Berdasarkan hasil penelitian, pembelajaran discovery learning telah dilaksanakan dengan langkah-langkah pembelajaran yang dikemukakan oleh DEDIKBUD (dalam Widyastuti, 2015) yaitu Stimulation (stimulasi/pemberian rangsangan), problem statement (pernyataan/identifikasi masalah), data collection (pengumpulan data), data processing 
(pengolahan data), verification (pembuktian), dan generalization (menarik kesimpulan/generalisasi).

Pada pertemuan pertama pembelajaran discovery learning belum terlaksana secara optimal, siswa terlihat asing terhadap model pembelajaran ini karena pada pembelajaran sebelumnya siswa belum pernah mendapatkan metode pembelajaran discovery learning, sehingga aktivitas siswa masih cenderung pasif. Pada awal pembelajaran penulis menyajikan permasalahan selain itu juga peneliti mengajukan pertayaan yang harus diselesaikan oleh siswa berkaitan dengan materi himpunan. Masalah diberikan dalam upaya merangsang siswa untuk meningkatkan keinginan untuk memahami dan keinginan untuk menyelesaiakan masalah yang diberikan tersebut, setelah itu peneliti menyampaikan prosedur penemuan terbimbing untuk menyelesaikan permasalahn tersebut disamping itu guru memberikan pertanyaan, anjuran untuk membaca buku dan aktifitas lainnya yang mengarah kepada pemecahan masalah.

Pada tahap selanjutnya siswa mengidentifikasi masalah yang telah diberikan sebanyak muungkin untuk dipilih menajadi rumusan dalam bentuk hipotesis. pada tahap data collection siswa mengumpulkan informasi yang relevan dari buku teks berkaitan dengan rumusan yang telah ditentukan sebelumnya. Dari informasi yang telah didapat siswa diarahkan untuk mengolah informasi tersebut untuk ditafsirkan. Hasil temuan tersebut kemudian diverifikasi dengan hipotesis yang telah ditentukan. Setelah hipotesis tersebut dibuktikan, siswa melakukan generalisasi apa yang menjadi permasalahan awal untuk dijadikan prinsip umum dan berlaku untuk permasalahan yang sama.

\section{Kemampuan Pemahaman Matematis}

Tujuan pertama dari penelitian adalah untuk mengetahui perbedaan peningkatan kemampuan pemahaman matematis siswa antara siswa yang mendapatkan pembelajaran discovery learning dengan siswa yang mendapatkan pembelajaran konvensional. Dilihat dari data hasil tes kemampuan awal pemahaman matemais, terlihat bahwa rata-rata nilai untuk kelas eksperimen adalah 38,26 dan untuk kelas kontrol adalah 43,86. Hal ini menunjukan bahwa tidak terdapat perbedaan yang signifikan kemampuan awal pemahaman matematis antara siswa yang mendapatkan pembelajaran discovery leanring dengan siswa yang mendapatkan pembelajaran konvensional pada materi Himpunan, 
dalam artian kemampuan pemahaman matematis siswa kelas eksperimen dan kelas kontrol memiliki kemampuan awal yang sama.

Dilihat dari analisis $N$-gain, kelas eksperimen dan kelas kontrol mengalami peningkatan setelah diberikan pembelajaran, namun setelah dianalisis nilai $N$-gainnya tidak terdapat perbedaan peningkatan kemampuan pemahaman matematis yang signifikan antara yang siswa yang mendapatkan pembelajaran discovery learning dengan siswa yang mendapatkan pembelajaran konvensional.

Walaupun setelah dianalisis tidak terdapat perbedaan yang signifikan, tetapi jika dilihat dari nilai rata-rata peningkatan kemampuan pemahaman matematis siswa yang mendapatkan pembelajaran discovery learning lebih tinggi dari nilai rata-rata siswa yang mendapatkan pembelajaran konvensional.

Senada dengan hasil penelitian Mawaddah, S. dan Maryanti, R. (2016:76-85) mengutarakan bahwa kemampuan pemahaman konsep matematika siswa dalam pembelajaran matematika dengan menggunakan model penemuan terbimbing (discovery learning) secara keseluruhan berada pada kategori baik.

Dengan demikian disimpulkan bahwa peningkatan kemampuan pemecahan masalah secara keseluruhan untuk peningkatan siswa yang mendapatkan pembelajaran discovery learning lebih baik daripada siswa yang mendapatkan pembelajaran konvensional dilihat dari nilai rata-rata dan peningkatan untuk setiap kelas berada pada katergori sedang.

\section{Kemampuan Pemecahan Masalah Matematis}

Tujuan kedua dari penelitian ini adalah untuk mengetahui perbedaan peningkatan kemampuan pemecahan masalah matematis siswa antara siswa yang mendapatkan pembelaharan discovery learning dengan siswa yang mendapatkan pembelajaran konvensional. Dilihat dari tes kemampuan awal pemecahan masalah matematis, terlihat bahwa rata-rata untuk kelas eksperimen adalah 21,59 dan untuk kelas kontrol 22,04. Hal ini menunjukan bahwa tidak terdapat perbedaan kemampuan awal kemampuan pemecahan masalah matematis yang signifikan antara siswa yang mendapatkan pembelajaran discovery leanring dengan siswa yang mendapatkan pembelajaran konvensional pada materi Himpunan, hal tersebut menunjukan bahwa kemampuan awal pemecahan masalah matematis siswa yang mendapatkan pembelajaran discovery learning 
dengan siswa yang mendapatkan pembelajaran konvensional memiliki kemampuan awal yang sama.

Dilihat dari analisis $N$-gain, kelas eksperimen dan kelas kontrol mengalami peningkatan setelah diberikan pembelajaran, namun setelah dianalisis nilai $N$-gainnya terdapat perbedaan peningkatan kemampuan pemecahan masalah matematis yang signifikan antara yang siswa yang mendapatkan pembelajaran discovery learning dengan siswa yang mendapatkan pembelajaran konvensional. Perbedaan tersebut jika dilihat dari nilai rata-rata peningkatan siswa yang mendapatkan pembelajaran discovery learning lebih tinggi dari nilai rata-rata siswa yang mendapatkan pembelajaran konvensional.

Senada dengan hasil penelitian Ramadhani (2017:72) pada kelas XII SMA YPK medan: peningkatan kemampuan pemahaman matematis dan kemampuan pemecahan masalah matematis siswa yang memperoleh guided discovery learning berbantuan Autograph lebih tinggi daripada siswa yang memperoleh pembelajaran konvensional

Ditambah dengan hasil penelitian Gusmania, Y dan Marlita (2016:151) mengungkpakan bahwa metode discovery learning efektif terhadap kemampuan pemecahan masalah matematika siswa dan metode discovery learning lebih baik dibandingkan metode konvensional terhadap kemampuan pemecahan masalah matematis siswa.

Sedangkan hasil penelitian Putri, R.M dan Eliarti, W (2017:129) mengungkapkan kemampuan pemecahan masalah matematis siswa SMA yang memperoleh model pembelajaran CORE tidak lebih baik dari kemampuan pemecahan masalah matematis siswa SMA yang memperoleh model pembelajaran discovery learning.

Ditinjau dari kategori kemampaun awal matematis (KAM) perbedaan tersebut terjadi pada kelompok tinggi dengan sedang dan tinggi dengan rendah. Secara keseluruhan untuk peningkatan kemampuan pemecahan masalah matematis siswa kelas eksperimen tidak lepas dari peran pembalajaran discovery learning yang cukup efektif dibandingkan dengan siswa yang mendapatkan pembelajaran konvensional. Hal ini tidak terlepas dari karakteristik penelitian eksperimen yang dikemukakan oleh Russefendi (2006:5) :

Equivalen subjek dalam kelompok-kelompok yang berbeda perlu ada, agar bila ada hasil yang berbeda yang diperoleh oleh kelompok, itu bukan disebabkan karena equivalennya kelempok-kelompok itu, tapi karena adanya perlakuan. 
Sehingga disimpulkan bahwa peningkatan kemampuan pemecahan masalah matematis siswa yang mendapatkan pembelajaran discovery learning lebih baik daripada siswa yang mendapatkan pembelajaran konvensional.

\section{Keefektifan discovery learning}

Keefektifan pembelajaran discovery learning terhadap peningkatan kemampuan pemahaman matematis dan kemampuan pemecahan masalah matematis setelah dilakukan perhitungan dengan menggunakan Cohen $-d$, diperoleh tingkat keefektifan pembelajaran discovery learning terhadap kemampuan pemahaman matematis adalah sebesar 0,4 atau termasuk kedalam kategori sedang. Hal tersebut menunjukan kesesuaian terhadap hasil peningkatan kemampuan pemahaman masalah matemtis siswa yang berada pada kategori sedang pula.

Hasil dari observasi yang telah dilakukan menunjukan bahwa pada tahap pertama dipembelajaran discovery learning sebagian siswa masih mengalami kesulitan dalam memahami masalah dan mengidentifikasi masalah yang diberikan, sehingga pada saat itu guru lebih banyak berperan dalam menstimulus siswa dalam memahami dan mengindentifikasi masalah. Oleh sebab itu, peniliti menyimpulkan bahwa keefektifan pembelajaran discovery learning terhadap kemampuan pemahaman matematis berada pada ketegori sedang, dikarenakan pada proses pembelajaran guru lebih berperan dalam memahami masalah dan mengindentifikasi masalah.

Adapun keefektifan pembelajaran discovery learning terhadap kemampuan pemecahan masalah matemtis setelah dilakukan perhitungan dengan menggunakan Cohen $-d$ adalah sebesar 0,7 atau berada dalam kategori sedang. Hal ini juga menunjukan kesesuaian dengan hasil peningkatan kemampuan pemecahan masalah matematis yang berada pada kategori sedang pula.

Besarnya keefektifan pembelajaran discovery learning terhadap kemampuan pemecahan masalah matematis siswa lebih besar dibandingkan dengan kemampuan pemahaman matematis. Hal ini menurut peneliti dikarenakan pada proses pemecahan masalah matemtis siswa telah memiliki pemahaman matemtis yang mencukupi pada proses sebelumnya untuk menyelsaikan permasalahan yang diberikan. 


\section{Kesimpulan}

Berdasarkan data yang diperoleh dari hasil penelitian, analisis data, dan pengujian hipotesis yang dilakukan, maka dapat disimpulkan sebagai berikut : Peningkatan kemampuan pemahaman matematis siswa yang mendapatkan pembelajaran discovery learning dikategorikan sedang dan siswa yang mendapatkan pembelajaran konvensional dikategorikan sedang. Walaupun peningkatan kemampuan antara siswa yang mendapatkan pembelajaran discovery learning dan konvensioanl berada pada kategori sedang. Sehingga tidak terdapat perbedaan peningkatan kemampuan pemahaman matematis siswa antara siswa yang mendapatkan model discovery learning dengan siswa yang mendapatkan pembelajaran konvensional.

Peningkatan kemampuan pemecahan masalah matematis siswa yang mendapatkan pembelajaran discovery learning dikategorikan sedang dan siswa yang mendapatkan pembelajaran konvensional dikategorikan sedang. Walaupun peningkatan kemampuan pemecahan masalah matematis siswa antara siswa yang mendapatkan pembelajaran discovery learning dan konvensioanl berada pada kategori sedang, akan tetapi rerata peningkatan siswa yang mendapatkan pembelajaran discovery learning lebih tinggi daripada rerata peningkatan siswa yang mendapatkan pembelajaran konvensional. Adapun hasil dari pengujian hipotesis disimpulkan bahwa terdapat perbedaan peningkatan kemampuan pemecahan masalah matemtis siswa antara siswa yang mendapatan pembelajaran discovery learning dengan siswa yang mendapatkan pembelajaran konvensioanl.

Disamping itu berdasarkan hasil analisis effect size, maka diperoleh tingkat keefektifan pembelajaran discovery learning terhadap peningkatan kemampuan pemahaman dan kemampuan pemecahan masalah matematis siswa termasuk kedalam kategori sedang.

\section{Referensi}

Gusmania, Y. \& Marlita. (2016). Pengaruh Metode Discovery Learning Terhadap Kemampuan Pemecahan Masalah Matematis Siswa Kelas X Sman 5 Batam Tahun Pelajaran 2014/2015. Jurnal Pythagoras, 5(2): 151-157 Oktober 2016 ISSN Cetak : 2301-5314

Hake, R.R., (2002). Relationship Of Individual Student Normalized Learning Gains in Mechanics With Gender, Hight School Physics and Pretest Scores on Mathematics and Spatial Visualization. Jurnal Internasional Vol 1 No 1 
Hartono, (2016). Pengembangan Pembelajaran Penemuan Terbimbing Untuk Meningkatkan Berpikir Kritis Dan Motivasi Belajar Geometri Di SMP. PYTHAGORAS: Jurnal Pendidikan Matematika Volume 11 - Nomor 2, Desember 2016, 207-218.

Heriawan, A, dkk. (2012). Metodelogi Pembelajaran Kajian Teoritis Praktis. Banten: LP3G ( Lembaga Pembinaan dan Pengembangan Profesi Guru).

Indrawan, R \& Yaniawati, R. P. (2014). Metodologi Penelitian Kuantitatif, Kualitatif, dan Campuran untuk Manajemen, Pembangunan, dan Pendidikan. Bandung: Refika Aditama.

Komala, E. (2012). Pembelajaran Dengan Pendekatan Diskursif Untuk Meningkatkan Kemampuan Pemecahan Masalah Matematis Dan Self-Concept Siswa Sekolah Menengah Pertama. Tesis UPI Bandung: Tidak diterbitkan.

Kotrlik, J.W., dkk (2011). Reporting and Interpreting Effect Size in Quantitative Agricultural Education Research. Journal of Agricultural Education Volume 52, Number 1, 2011.132142.

Marpaung (2004). Artikel Universitas Negeri Medan. Tersedia: http://digilib.unimed.ac.id/3156/6/1500081188730055\%20Bab\%20I.pdf $\quad[07$ Agustus 2017].

Mawaddah, S. \& Maryanti, R. (2016). Kemampuan Pemahaman Konsep Matematis Siswa Smp Dalam Pembelajaran Menggunakan Model Penemuan Terbimbing (Discovery Learning). Edu-Mat Jurnal Pendidikan Matematika, Volume 4, Nomor 1, April 2016, 76 - 85

Nurliani, E. (2014). Meningkatkan Kemampuan Pemahaman dan Pemecahan Masalah Matematis Siswa Melalui Model Pembelajaran Berbasis Masalah.[online] Tersedia : http://repository.unpas.ac.id/9555/ [ 9 September 2017].

Putri, R.M. \& Eliarti, W. (2017). Perbandingan Model Pembelajaran Core Dengan Discovery Learning Dalam Pembelajaran Matematika Terhadap Kemampuan Pemecahan Masalah Matematis Dan Self-Regulated Learning Siswa Sma. Pasundan Journal Of Research In Mathematics Learning And Education Volume 2 Nomor 2, Desember 2017 ISSN 2548-2297

Ramadhani, R. (2017). Peningkatan Kemampuan Pemahaman Konsep dan Kemampuan Pemecahan Masalah Matematik Siswa Melalui Guide Discovery Learning Berbantu Autograph. Jurnal JPPM Vol. 10. No. 2.

Russefendi, E.T. (2006). Pengantar Kepada Membantu Guru Mengembangkan Kompetensinya dalam Pembelajaran Matematika untuk Meningkatkan CBSA. Bandung : Tarsito

Wati, W, \& Fatimah, R. (2016). Effect Size Model Pembelajaran Kooperatif Tipe Numbered Heads Together (Nht) Terhadap Kemampuan Berpikir Kritis Siswa Pada Pembelajaran Fisika. Jurnal Ilmiah Pendidikan Fisika 'Al-Biruni' 05 (2), 2016. 213-222 
Widura, H.S. (2015). Pengaruh Model Guided Discovery Learning Terhadap Kemampuan Berpikir Kritis Siswa Kelas X Sma Negeri 8 Surakarta Tahun Pelajaran 2014/2015. Jurnal BIO-PEDAGOGI 4 (2), Oktober 2015. 25 - 30.

Widyastuti, E.S. (2015). Penerapan Model Pembelajaran Discovery Learning Pada Materi Konsep Ilmu Ekonomi. Prosiding Seminar Nasional 9 Mei 2015 